doi: $10.3935 /$ rsp.v25i3.1550

\section{OSNOVE POREZNE PISMENOSTI}

\section{Nika Šimurina, Ivana Dražić Lutilsky, Dajana Barbarić, Martina Dragija Kostić}

Zagreb: Narodne novine, 2018., 204 str.

Porezi su možda najvažniji pokretač povijesti i vjerojatno zaslužuje mnogo veću pozornost i poznavanje nego mnoge druge povijesne teorije koje su prilično lomljive i slabe poput klasne borbe, životnih ciklusa, velikih junaka i sl. Bez obzira na presudnu ulogu koju su porezi imali tijekom razvoja čovječanstva, zbog njihove prirode i složenosti znanja o njima u svijetu, a pogotovo u Hrvatskoj, su vrlo slaba. Autorice su željele na lak i razumljiv način pojasniti značenje i obilježja cjelokupnog poreznog sustava i pojedinih poreznih oblika što bi građanima trebalo biti od velike važnosti u lakšem ispunjavanju njihove porezne obveze. Gotovo ne treba podsjećati koliko su porezi važni i u socijalnoj politici kao način prikupljanja sredstava za financiranje socijalnih potreba, a ujedno mogu biti i velik teret siromašnijim osobama.

U prvom poglavlju Porezna pismenost i porezno ponašanje, Dajana Barbarić pojašnjava neumitnost poreza i mnogobrojne oblike u kojima se oni javljaju. U dionici o poreznoj pismenosti, jedne od dimenzija financijske pismenosti, autorica izlaže njezinu važnost koja se može promatrati iz aspekta pojedinca (planiranja osobnih financija i određivanja osobne porezne pozicije) te iz aspekta države (urednog podmirenja poreznih obveza prema državi). Ujedno, vrlo je lijepo i razumljivo objašnjena važnost porezne pismenosti kao važne odrednice uspješnog prikupljanja javnih prihoda.
Obilježja poreznih i neporeznih davanja predmet su izlaganja drugog poglavlja u kojem Nika Šimurina tumači razlike poreza prema njihovim obilježjima, funkcijama i izdašnosti. Porezi predstavljaju najvažniji i najizdašniji oblik javnog prihoda države, a postoje još od vremena prvih organiziranih ljudskih zajednica. Autorica nakon kratke povijesti razvoja poreznih oblika pojašnjava kako se javni prihodi u suvremenim državama značajno razlikuju zbog utjecaja mnogobrojnih čimbenika poput veličine teritorija i broja stanovnika, veličine javnog sektora i njegovih zadaća, stupnja (de)centralizacije, pripadnosti pojedinim ekonomskim unijama i drugih odrednica. Odgovarajuća pozornost posvećuje se klasifikaciji i opisu pojedinih oblika javnih prihoda. Autorica također tumači obilježja koja imaju porezi kao što su prisilnost, izvedenost, nepovratnost poreza i drugo. Ovo poglavlje završava opisom pojma i obilježja neporeznih davanja, od kojih su najznačajniji doprinosi za socijalno osiguranje. Najvažnija razlika između ovih davanja i poreza jest što su doprinosi većinom namjenski za određenu svrhu, a porezi to nisu.

Nika Šimurina je autorica i trećeg poglavlja u kojem izlaže mjesto i ulogu poreza u poreznom sustavu. Autorica posebnu pozornost posvećuje poreznoj evaziji što je nezakoniti način smanjenja poreznih obveza, primjerice, podcjenjivanjem ostvarenog dohotka ili iskazivanjem većih poslovnih odbitaka. Porezna evazija implicitno povećava javni deficit, a najveći je gubitnik uredni porezni obveznik, jer država istu vrijednost pruženih usluga financira sve skupljim kapitalom ili je prisiljena povećati poreznu presiju na legalni dio gospodarstva.

U četvrtom poglavlju tumači se problematika izravnih ili neposrednih poreza kod kojih je oporezivanje povezano izravno uz samu osobu poreznog obveznika (fizičku 
ili pravnu osobu), odnosno gdje nema prevaljivanja poreza. Porezni su stručnjaci već dugo vremena svjesni postojanja razlike između točke u kojoj su porezi nametnuti (njihove »zakonom propisane« incidencije) i »konačne« točke na kojoj leži porezno opterećenje. U ovom dijelu publikacije posebno treba pohvaliti jasno objašnjavanje različitih modaliteta oporezivanja: engleski ili cedularni, germanski ili sintetički i romanski model, te opravdanosti uvođenja proporcionalnog poreza (eng. flat tax). U tekstu se također odgovarajuća pozornost usmjerava na načine izbjegavanja međunarodnog dvostrukog oporezivanja, najčešće putem bilateralnih ugovora.

Predmet izlaganja Dajane Barbarić u petom poglavlju su neizravni porezi. U Hrvatskoj su to porez na promet, porez na dodanu vrijednost, trošarine, porez na promet nekretnina i carine. Ukupno prikupljena sredstva iz navedenih poreza čine 52\% ukupnih poreznih prihoda u Hrvatskoj. Sa stanovišta izdašnosti, u Hrvatskoj je najznačajniji porez na dodanu vrijednost (PDV), što je jedan od oblika općeg poreza na promet. Njegovo je uvođenje u Hrvatskoj odgađano do početka siječnja 1998. godine, a usvajanjem tog poreznog oblika, završena je fiskalna reforma koja je trajala od osamostaljenja Hrvatske. PDV ima više pozitivnih obilježja, prije svega neutralnost, izostanak kumulativnog (kaskadnog) učinka i uspješan je način sprječavanja porezne evazije. Njegova nepovoljna obilježja su ponajviše regresivni učinak - više opterećuje siromašne pa je narušeno pravilo porezne pravednosti. U neizravne poreze ubrajaju se i trošarine (na primjer na cigarete ili alkohol) koje su u povijesti od samih svojih početaka potaknule porezne obveznike na krijumčarenje. One su nakon PDV-a najvažniji izvor proračunskih prihoda jer su prilično izdašne i razmjerno jednostavne za ubiranje. Trošarine su ujed- no način za pokrivanje troškova vanjskih učinaka (eksternalija) koji nastaju zbog korištenja alkohola, duhana i drugih štetnih proizvoda, a manje ili više uspješno demotiviraju građane na potrošnju nezdravih proizvoda, kao što je duhan.

Porezni obveznik može istovremeno ostvarivati više vrsta dohodaka, a za svaki od različitih vrsta dohodaka plaća se porez. Taj je sustav dosta složen i zahtjevan jer se primjenjuje drugačiji obračun, pa se ovisno o vrsti dohotka utvrđuje godišnji ili konačni dohodak. Stoga je više nego hvalevrijedno da u šestom poglavlju publikacije Martina Dragija Kostić na lako razumljiv način objašnjava računovodstvene aspekte poreza na dohodak. Autorica u tekstu na mnogobrojnim primjerima prikazuje elemente obračuna poreza na dohodak, s time da u pojašnjenjima dodatno izlaže pojedinosti svakog pojedinog koraka obračuna. Posebno je vrijedno pojašnjenje obračuna drugog dohotka koji obuhvaća primitke na temelju nesamostalnog rada, samostalne djelatnosti, imovine i imovinskih prava, kapitala i osiguranja.

$\mathrm{Na}$ sličan način u sedmom poglavlju Ivana Dražić Lutilsky tumači računovodstvo poreza na dobit. Taj je porezni oblik na razini Europske unije prilično neusklađen u pojedinim državama članicama stoga što je oporezivanje dohotka i dobiti još uglavnom u nadležnosti nacionalnog gospodarstva. Iako je obveznik poreza na dobit uglavnom pravna osoba, u hrvatskom sustavu oporezivanja dobiti postoji specifičnost što pod određenim uvjetima i fizička osoba (obrtnik i s obrtom izjednačena zanimanja) može postati obveznikom u sustavu poreza na dobit. Odnedavno za ustanove i udruge koje nisu osnovane radi ostvarivanja dobiti, ali u manjem opsegu obavljaju i gospodarsku djelatnost, postoji mogućnost paušalnog plaćanja poreza na dobit. Autorica posebno jasno objašnjava stalne i pri- 
vremene razlike između dobiti ili gubitka u računovodstvu i porezne osnovice. Jedna od mogućnosti kako porezni obveznik može platiti manji porez na zakonit način je korištenjem poreznih pogodnosti, odnosno povećati stope amortizacije do maksimalno porezno priznatih rashoda.

Posljednje, osmo, poglavlje isto je pripremila Ivana Dražić Lutilsky. Ovo je poglavlje posvećeno računovodstvu poreza na dodanu vrijednost (PDV) koji se kroz cijenu dobra ili usluge prevaljuje na krajnjeg potrošača. U odnosu na običan porez na promet, porezna je evazija osjetno manja: kupac podnosi izvještaj poreznim vlastima s namjerom da ostvari umanjivanje poreza, dok će prodavač - koji plaća porez na dodanu vrijednost - vjerojatno podnijeti točnu prijavu. Dodatni argument $\mathrm{u}$ prilog poreza na dodanu vrijednost je njegova široka prihvaćenost u mnogim razvijenim zemljama. Kako smo već naveli, PDV je u Hrvatskoj najizdašniji porezni izvor, pa je u radu odgovarajuća pozornost posvećena tumačenju pojedinosti sustava PDV-a kod nas. U Hrvatskoj postoje tri stope PDV-a: standardna stopa od $25 \%$ te snižene stope od $13 \%$ i $5 \%$. Razdoblje oporezivanja je kalendarska godina, odnosno razdoblje poslovanja ako je porezni obveznik poslovao samo tijekom dijela godine. $\mathrm{Na}$ čak 10 različitih primjera autorica jasno pojašnjava obračun i plaćanje PDV-a

Ovo je vrlo zanimljiva publikacija o značenju, obilježjima i složenosti poreznog sustava koja bi u značajnoj mjeri trebala pomoći boljem poznavanju građana zašto i koliko plaćaju porez. Sa sigurnošću se može ocijeniti kako su porezna pismenost i porezna kultura na niskoj razini, zaostaju za promjenom i vrlo se teško prilagođavaju. To se prije svega odnosi na porezne obveznike koji se i dalje ponašaju prema unaprijed naučenim obrascima i čije se navike i stavovi mnogo sporije mijenjaju.
Ova je publikacija više nego dobrodošla u unaprjeđenju porezne pismenosti, a dosad u Hrvatskoj nije provedeno niti jedno istraživanje ili objavljena publikacija koja bi se bavila navedenom problematikom.

Predrag Bejaković

Institut za javne financije, Zagreb 